\title{
MOTIVASI SISWA DALAM AKTIVITAS PENGEMANGAN DIRI BIDANG KEPRAMUKAAN DI GUGUS DEPAN SDN 22 ULAK KARANG UTARA KOTA PADANG
}

\author{
Zarwan $^{1}$, Rosmawati ${ }^{2}$, Arsil $^{3}$ \\ Program Studi Pendidikan Jasmani Kesehatan dan Rekreasi, Fakultas Ilmu Keolahragaan, Universitas \\ Negeri Padang, Jalan Prof. DR. Hamka Air Tawar Barat, Padang, 25132, Indonesia \\ Email: zarwan@fik.unp.ac.id ${ }^{1}, \underline{\text { rosmawati@fik.unp.ac.id }}^{2}, \underline{\text { arsil @ fik.unp.ac.id }}^{3}$,
}

\begin{abstract}
Abstrak
Masalah dalam penelitian berawal dari kurang terlaksananya kegiatan kepramukaan di Gugus Depan SDN 22 Ulak Karang Utara Kota Padang. Tujuan penelitian ini untuk mengetahui motivasi instrinsik dan ekstrinsik siswa dalam kegiatan kepramukaan di Gugus Depan SDN 22 Ulak Karang Utara Kota Padang.

Jenis penelitian ini adalah penelitian deskriptif yaitu suatu penelitian yang bertujuan untuk mendeskripsikan atau menggambarkan keadaan atau kondisi pada saat penelitian. Populasi dalam penelitian seluruh siswa yang mengikuti kegiatan pramuka yang berjumlah 30 orang. Teknik penarikan sampel yang digunakan dalam penelitian ini yaitu total sampling, dimana seluruh populasi dijadikan sampel yaitu 30 orang. Alat pengumpul data adalah angket dengan skala Likert. Data di analisis dengan statistik deskriptif dengan teknik persentase.

Hasil penelitian diperoleh sebagai berikut : (1) Motivasi intrinsik siswa dalam aktivitas pengembangan diri bidang kepramukaan di Gugus Depan SDN 22 Ulak Karang Utara Kota Padang sebesar 73.83\%, termasuk klasifikasi "Sedang". 2) Motivasi ekstrinsik siswa dalam aktivitas pengembangan diri bidang kepramukaan di Gugus Depan SDN 22 Ulak Karang Utara Kota sebesar 69.97\%, termasuk klasifikasi "Sedang". Berdasarkan temuan ini dapat disimpulkan bahwa motivasi siswa dalam aktivitas pengemangan diri Bidang Kepramukaan di Gugus Depan SDN 22 Ulak Karang Utara Kota Padang termasuk klasifikasi "Sedang" dan perlu ditingkatkan lagi.
\end{abstract}

Kata Kunci: Motivasi Siswa, Pengembangan Diri, Kepramukaan

\section{PENDAHULUAN}

Keputusan Musyawarah Nasional Gerakan Pramuka Nomor : 10/Munas/2003 tentang Rencana Strategik Gerakan Pramuka 2004-2009, yang menjadi tujuan dan sasaran dari pendidikan kepramukaan adalah;

“1) Membentuk kader pembangunan bangsa Indonesia yang berwawasan ilmu pengetahuan dan teknologi, 2) Untuk menangkal kenakalan remaja. 3) Meningkatkan Iman dan ketaqwaan kepada Tuhan Yang Maha Esa, 4) Pembinaan mental dan moral, 3) Pembinaan jasmani yang sehat, segar dan kuat, 4) Peningkatan kecerdasan, keterampilan dan ketangkasan, 5) Pembinaan jiwa kepemimpinan dan rasa tanggung jawab atas keluarga, masyarakat, bangsa dan negara, 6) Pembinaan pengetahuan, berbudaya dan patriotisme, 7) Menanamkan pengalaman dan wawasan, 8) Meningkatkan kesadaran sosial, kepedulian terhadap keadaan dan perubahan lingkungan serta kesanggupan untuk membangun". (Munas Gerakan Pramuka 2003, hal 10)".

Dengan demikian jelaslah akan pentingnya kepramukaan bagi anak-anak muda di seluruh Indonesia. Untuk mewujudkan semua itu, pelaksanaan kegiatan kepramukaan seharusnya berjalan sesuai dengan Keputusan Musyawarah Nasional Gerakan Pramuka Nomor : 10/Munas/2003 
tentang Rencana Strategik Gerakan Pramuka 2004-2009 tersebut.

Gerakan pramuka adalah suatu gerakan pendidikan non formal yang melengkapi pendidikan jalur non formal maupun informal. Melihat tujuan, prinsip dan metode yang telah ditetapkan, kepramukaan mampu menjadi salah satu kekuatan perubahan sosial nasional.

Sampai saat ini masih mengalami krisis dalam semua aspek kehidupan sosial. Suatu yang sangat memprihatinkan adalah krisis dalam nilai-nilai akhlak, mental dan moral di masyarakat yang berkaitan dengan pembentukan watak, sikap, tingkah laku dan budi pekerti.

Tantangan utama yang dihadapi adalah bagaimana cara dan usaha untuk menghadapi berbagai perubahan besar yang akan mempengaruhi atau berdampak pada kaum muda. Kegiatan pramukan merupakan salah satu diantara kegiatan yang berkelanjutan yang mampu menunjang tercapainya tujuan pendidikan

Adapun tujuan dari Gerakan Pramuka adalah membinan kaum muda Indonesia guna mengembangkan mental, moral, spiritual, emosional, sosial, intelektual dan fisiknya.

Berdasarkan observasi dan wawancara penulis dengan kepala sekolah, guru, siswa dan orang tua siswa yang ada di SD Negeri 22 Ulak Karang Utara Kota Padang pada umumnya mengatakan bahwa pelaksanaan kegiatan pengembangan diri bidang kepramukaan masih belum berjalan dengan baik, buktinya siswa lebih memilih pulang ke rumah dari pada mengikuti kegiatan pramuka.

Rendahnya motivasi siswa untuk mengikuti kegiatan kepramukaan. Kurangnya peranan guru kelas terhadap pembinaan pramuka. Kurangnya pembina pramuka yang mengerti akan kepramukaan. Kurangnya dukungan orang tua terhadap kegiatan pramuka.
Gerakan Pramuka, adalah nama organisasi pendidikan luar sekolah yang menggunakan Prinsip Dasar Kepramukaan dan Metode Kepramukaan.

Dengan kata lain Gerakan Pramuka adalah suatu gerakan pendidikan untuk kaum muda, yang bersifat sukarela, non politik, terbuka untuk semua, tanpa membedakan asal-usul, ras, suku dan agama, yang menyelenggarakan kepramukaan melalui suatu sistem nilai yang didasarkan pada Satya dan Darma Pramuka.

Sedangkan kepramukaan (Scouting), adalah proses atau kegiatan anggota Gerakan Pramuka seperti yang tertuang dalam AD/ART Gerakan Pramuka bahwa kepramukaan adalah proses pendidikan di luar lingkungan sekolah dan di luar lingkungan keluarga dalam bentuk kegiatan menarik, menyenangkan, sehat, teratur, terarah dan praktis, dilakukan di alam terbuka dengan menggunakan prinsip dasar kepramukaan dan metode kepramukaan.

Sasarannya adalah pembentukan watak, akhlak mulia (budi pekerti luhur). Dengan demikian kepramukaan mempunyai dua nilai, yaitu Nilai formal, atau nilai pendidikan yakni pembentukan watak (character budding) dan Nilai materil, yaitu nilai praktisnya.

Kedua nilai ini berjalan secara serasi dan seimbang sesuai dengan pertumbuhan dan perkembangan anak didik. Untuk menjalankan kegiatan tersebut. Kepramukaan memiliki 3 pilar yang selalu menjadi pedoman di semua kegiatan kepramukaan, pilar tersebut adalah : 1) Modern, yaitu selalu mengikuti perkembangan, 2) Asas manfaat, yaitu kegiatan yang selalu memperhatikan manfaat dan tujuan yang akan dicapai oleh peserta didik, 3) Asas taat pada kode kehormatan, yaitu dapat mengembangkan karakter peserta didik ke arah yang lebih baik.

Pengembangan tiga pilar yang didasari dengan lima unsur utama ini didasarkan pada 
Sifat-sifat yang terdapat pada kepramukaan, yaitu nasional, internasional dan universal.

Semua anggota pramuka ini menjalankan tugas sesuai dengan fungsinya masing-masing. Dalam pembukaan Keppres RI Nomor 104 (2004;2) dijelaskan. bahwa setiap anggota Pramuka dibentuk karena dorongan kesadaran masing-masing dan bertanggung jawab atas kelestarian Negara Kesatuan Republik Indonesia yang berdasarkan Pancasila dan Undang-Undang Dasar 1945.

Dari kutipan di atas dapat di . jelaskan bahwa Pramuka merupakan objek yang melaksanakan kegiatan kepramukaan, dalam rangka mewujudkan masyarakat yang madani, dan melestarikan keutuhan Negara kesatuan Republik Indonesia, serta kehidupan rakyat yang rukun dan damai.

Dasar dan Metode Kepramukaan. Pelaksanaannya disesuaikan dengan struktur yang telah ditentukan secara nasional mulai dari tingkat Kwarnas, Kwarda, Kwarcab, Kwaran sampai ketingkat Gugus depan. Gugus depanlah yang nantinya sebagai ujung tombak kegiatan kepramukaan.

Prinsip Dasar dan metode kepramukaan seperti yang dijelaskan dalam Anggaran Dasar Gerakan Pramuka merupakan ciri khas yang membedakan kepramukaan dari pendidikan lain.

Pada Pasal II Anggaran Dasar Gerakan Pramuka dijelaskan secara khusus tentang prinsip dasar kepramukaan yaitu prinsip dasar kepramukaan memiliki empat hal pokok, yaitu :

1. Iman dan takwa kepada tuhan YME

2. Peduli terhadap bangsa, negara, sesama manusia dan alam serta isinya.

3. Peduli terhadap diri sendiri.

4. Taat kepada Kode Kehormatan Pramuka.

Keempat prinsip ini merupakan rangkaian yang tidak dapat dipisahkan dalam menjalankan kegiatan kepramukaan.
Semua anggota pramuka wajib mentaati keempat prinsip ini. Fungsinya adalah :
1) Norma hidup anggota Gerakan Pramuka
2) Landasan kode etik Gerakan Pramuka.
3) Landasan sistem nilai Gerakan Pramuka.

4) Pedoman dan arah pembinaan kaum muda anggota Gerakan Pramuka.

5) Landasan gerak dan kegiatan pramuka dalam mencapai sasaran dan tujuannya.

Berdasarkan kutipan di atas dapat dijelaskan bahwa prinsip dasar merupakan pedoman yang mendasar dalam berpikir dan bertindak. Prinsip adalah sebuah pondasi, makin kuat penjiwaan prinsip dasar kepramukaan dalam diri peserta didik, makin kuat pula jiwa kepramukaannya.

Dengan arti prinsip dasar kepramukaan merupakan seperangkat jiwa dan tata nilai/norma hidup yang dimiliki seorang pramuka dalam bertingkah laku sehari-hari baik sebagai makhluk Tuhan maupun sebagai anggota masyarakat.

Disinilah yang membedakan pendidikan kepramukaan dengan pendidikan lainnya. Motovasi didefenisikan sebagai sesuatu yang memberi daya pendorong untuk berperilaku dengan menggerakkan, menopang, dan mengarahkan menuju citacita yang hendak dicapai.

Bareson dalam Steiner dalam Ilyas, (2000:129) mendefenisikan motivasi sebagai "all those inner striving conditions variously described as wishes,desires, needs, drives, and the likes".

Yang artinya sebagai kondisi internal, kejiwaan dan mental manusia seperti aneka keinginan, harapan, kebutuhan, dorongan dan kesukaan yang mendorong individu untuk berperilaku kerja untuk mencapai kepuasan atau mengurangi ketidak seimbangan. 
Berdasarkan beberapa pendapat yang telah dikemukakan di atas tentang pengertian motivasi, maka dapat ditarik suatu kesimpulan bahwa motivasi merupakan adanya perubahan energi dalam diri seseorang, yang disebabkan adanya dorongan dalam dirinya untuk berbuat dalam mencapai tujuan yang diinginkan.

Artinya seseorang yang memiliki motivasi yang tinggi dalam dirinya, seperti dalam perkuliahan bolavoli dasar, maka akan muncul dalam dirinya suatu dorongan yang kuat untuk berbuat dengan tujuan yang telah ditetapkan dan diinginkan untuk mencapai suatu kepuasan.

Fungsi motivasi selain sebagai faktor yang mendorong untuk melakukan tindakan atau perbuatan, motivasi juga merupakan faktor yang akan mengarahkan dan menggerakkan siswa untuk melakukan perbuatan atau tindakan yang berkaitan dengan pencapaian tujuan.

Dengan terwujudnya motivasi kedalam bentuk tingkah laku maka dapat diketahui dan diramalkan apa yang menjadi tujuan permainan bolavoli.

Motivasi Instrinsik yaitu keinginan seseorang untuk mencapai tujuan yang diharapkan adakalanya dapat disebabkan oleh faktor pendorong dan kekuatan dari alam

dirinya, yang biasanya disebut dengan motiva si instrinsik.

Motivasi instrinsik bisa juga dikatakan dorongan yang berasal dari dalam diri individu untuk berprestasi mengerjakan sesuatu yang bukan karena situasi buatan atau mengharapkan penghargaan tertentu, tetapi hanya untuk mencapai kepuasan dirinya.

Seorang anak yang mempunyai motivasi instrinsik akan mengikuti proses pembelajaran karena menemukan kepuasan dalam dirinya dan bukan disebabkan oleh situasi buatan (dorongan dari luar) seperti pemberian hadiah, pujian dan penghargaan lainnya.

Anak didik yang melakukan motivasi ini untuk meningkatkan semngat belajar, dan tidak tergantung pada orang lain, memiliki kepribadian yang matang, jujur, sportif, percaya diri, dan kreatif. Menurut Setyobroto (2002 : 65) bahwa terdapat tiga motif utama dalam motivasi instrinsik yaitu (1) Motif aktualisasi, (2) Motif berprestasi (3) Motif kebanggaan.

Motivasi Ekstrinsik yaitu motivasi yang dipengaruhi ransangan dari luar diri seseorang disebut juga dengan motivasi ekstrinsik.

Semiawan (1996) menyatakan motivasi eksrinsik sebagai kekuatan yang mendorongnya untuk memenuhi kebutuhann ya.

Dalam mengembangkan pribadi dan watak peserta didik dibutuhkan seseorang yang mau dan mampu bertanggung jawab menjalankan kegiatan yang dilakukan di luar kegiatan sekolah (dikenal dengan pembina pramuka).

Pembina pramuka adalah seseorang yang diberikan tanggung jawab oleh sekolah atau lembaga tertentu, untuk menjalankan kegiatan kepramukaan kepada anak-anak dan remaja.

Oleh karena itu, yang sangat memprihatinkan saat ini adalah, banyaknya Pembina pramuka yang tidak menerapkan metode kepramukaan, sehingga permasalahan pembinaannya kurang berjalan dengan sesuai dengan konsep kepramukaan. Seiring dengan itu jumlah pembina juga menjadi masalah, terutama yang memiliki sertifikasi pelatih.

Syarat untuk menjadi pelatih pramuka minimal sudah memiliki sertifikat mahir, yaitu KMD/KML dengan perbandingan idealnya antara Pembina dengan peserta didik $1: 10$.

Jika dalam satu gudep memiliki 40 orang peserta didik, maka jumlah pembina seharusnya 5 orang, sehingga dengan jumlah 
perbandingan ini perhatian dan hasil yang diharapkan dapat dicapai secara optimal.

\section{Metode dan Hasil}

penelitiannya termasuk penelitian deskriptif, dengan tujuan untuk menggambarkan atau mengetahui pengembangan diri bidang kepramuka secara pasti.

Penelitian ini dilaksanakan pada SDN 22 Ulak Karang Utara Kota Padang. Penelitian ini dilaksanakan pada bulan Mei 2014.

Dalam penelitian ini yang menjadi populasi adalah siswa yang mengikuti pengembangan diri bidang kepramuka di Gugus Depan SDN 22 Ulak Karang Utara Kota Padang dengan jumlah 30 orang, terdiri dari 20 siswa putra, dan 10 siswa putri.

\section{Tabel 1. Populasi Penelitian}

\begin{tabular}{|c|c|c|}
\hline Putra & Putri & Jumlah \\
\hline 20 & 10 & 30 \\
\hline
\end{tabular}

Sampel di penelitian ini menggunakan teknik total sampling atau di mana semua Populasi dijadikan sampel (Arikunto :1990), seehingga jumlah sampel 30 orang.

Jenis Data dalam penelitian ini adalah data primer yang diperoleh langsung dari responden dan data sekunder dari tata usaha sekolah. Sumber data dalam penelitian ini adalah siswa SD Negeri 22 yang aktif mengikuti pengembangan diri bidang kepramuka, dan ditambah dengan beberapa guru sekolah untuk mendapatkan informasi yang lebih akurat.

\section{Teknik dan Alat Pengumpulan Data}

Untuk mendapatkan data dalam penelitian ini penulis menggunakan kuesioner (angket). Angket digunakan untuk menyaring jawaban dari siswa SDN 22 Ulak Karang Utara Kota Padang, yang bertujuan untuk mendapatkan gambaran tentang motivasi siswa di dalam pengembangan diri bidang kepramukaan.

Adapun keterbatasan angket ini adalah kesulitan bagi responden untuk menyampaikan alasannya karena yang digunakan adalah angket tertutup. Selanjutnya untuk mendapatkan data dalam penelitian ini.

Peneliti menggunakan angket sebagai pengumpul data dan disusun dengan menggunakan Skala Likert yang terdiri dari lima kategori yaitu, Sangat Setuju (SST) dengan skor 5, Setuju (ST) dengan skor 4, Ragu-Ragu (RR) dengan skor 3, Tidak Setuju (TS) dengan skor 2, dan Sangat Tidak Setuju (STS) dengan skor 1.

Berdasarkan penelitian deskriptif, Arikunto (1990) menyatakan data yang terkumpul akan dianalisis dengan menggunakan rumus sebagai berikut:

$$
P=\frac{f}{N}
$$

Keterangan :

$\mathrm{P}=$ Presentase hasil yang diperoleh

$\mathrm{F}=$ Frekuensi dari masing- masing jawaban $\mathrm{n}=$ Jumlah responden.

(Yusuf: 1997, 40).

\section{HASIL DAN PEMBAHASAN}

Deskripsi data yang dilakukan dalam penelitian ini adalah untuk melihat karakteristik distribusi data dan indikator pertanyaan yang meliputi aspek tentang motivasi intrinsik dan motivasi ekstrinsik. Dalam analisis ini semua da ing sudah terkumpul, diolah dan dic sa sesuai dengan cara dan ketentuan yang telah dikemukakan pada bab yang terdahulu. Untuk lebih jelasnya berikut disajikan secara berurutan :

\section{Motivasi Intrinsik}

Dari hasil analisis data untuk untuk sub variabel motivasi Intrinsik siswa dalam aktivitas pengembangan diri bidang kepramukaan di SDN 22 Ulak Karang Utara Kota Padang diberikan 16 item pertanyaan kepada 30 orang siswa yang dijadikan sebagai responden, diperoleh nilai tertinggi 93.75 dan nilai terenda 50 . 
Berdasarkan data kelompok tersebut rata-rata hitung (mean) 73.83, simpangan baku (standar deviasi) 12.70. Selanjutnya distribusi motivasi instrinsik siswa dapat dilihat pada tabel 2.

Tabel 2. Distribusi Frekuensi Data Motivasi Instrinsik

\begin{tabular}{|c|c|c|c|}
\hline Skor & Kategori & $\begin{array}{c}\text { Frekuensi } \\
\text { Absolut }\end{array}$ & $\begin{array}{c}\text { Frekuensi } \\
\text { Relatif } \\
(\%)\end{array}$ \\
\hline $90-$ & $\begin{array}{c}\text { Baik } \\
\text { Sekali }\end{array}$ & 2 & 6.67 \\
\hline $79-89$ & Baik & 11 & 36.67 \\
\hline $65-78$ & Sedang & 9 & 30 \\
\hline $55-64$ & Kurang & 5 & 16.66 \\
\hline $0-54$ & $\begin{array}{c}\text { Kurang } \\
\text { Baik }\end{array}$ & 3 & 10 \\
\hline Jumlah & 30 & $100 \%$ & \multicolumn{1}{|c}{} \\
\cline { 1 - 3 } & &
\end{tabular}

Berdasarkan tabel 2 distribusi frekuensi di atas, maka dapat disimpulkan bahwa dari 30 orang siswa SDN 22 Ulak Karang Utara Kota Padang yang dijadikan sebagai sampel dalam penelitian ini, 2 orang $(6.67 \%)$ memiliki motivasi instrinsik kategori baik sekali, 11 orang $(36.67 \%)$ siswa yang memiliki motivasi instrinsik dalam kategori baik. 9 orang (30\%) siswa yang memiliki motivasi instrinsik dalam kategori sedang, 5 orang (16.66\%) siswa memiliki motivasi instrinsik kategori kurang, dan 3 orang (10\%) siswa memiliki motivasi instrinsik kategori kurang baik.

\section{Motivasi Ektrinsik}

Dari hasil analisis data untuk untuk sub variabel motivasi ekstrinsik siswa dalam aktivitas pengembangan diri bidang kepramukaan di SDN 22 Ulak Karang Utara Kota Padang diberikan 24 item pertanyaan kepada 30 orang siswa yang dijadikan sebagai responden, diperoleh nilai tertinggi 85.83 dan nilai terendah 41.66. Berdasarkan data kelompok tersebut rata-rata hitung (mean) 69.97, simpangan baku (standar deviasi) 8.86. Selanjutnya distribusi motivasi instrinsik siswa dapat dilihat pada tabel 3 .
Tabel 3. Distribusi Frekuensi Data Motivasi Ekstrinsik

\begin{tabular}{|c|c|c|c|}
\hline Skor & Kategori & $\begin{array}{c}\text { Frekuensi } \\
\text { Absolut }\end{array}$ & $\begin{array}{c}\text { Frekuensi } \\
\text { Relatif } \\
(\%)\end{array}$ \\
\hline $90-$ & $\begin{array}{c}\text { Baik } \\
\text { Sekali }\end{array}$ & 0 & \\
\hline $79-89$ & Baik & 3 & 10 \\
\hline $65-78$ & Sedang & 19 & 63.34 \\
\hline $55-64$ & Kurang & 7 & 23.33 \\
\hline $0-54$ & $\begin{array}{c}\text { Kurang } \\
\text { Baik }\end{array}$ & 1 & 3.33 \\
\hline Jumlah & 30 & 100 & \multicolumn{1}{|c}{} \\
\cline { 1 - 3 }
\end{tabular}

Berdasarkan tabel 3 di 27 i frekuensi di atas, maka dapat disimpı ahwa dari 30 orang siswa SDN 22 Ulak Karang Utara Kota Padang yang dijadikan sebagai sampel dalam penelitian ini, tidak ada siswa yang memiliki motivasi ekstrinsik kategori baik sekali, 3 orang (10\%) siswa yang memiliki motivasi ekstrinsik dalam kategori baik. 19 orang (63.34\%) siswa yang memiliki motivasi ekstrinsik dalam kategori sedang, 7 orang $(23.33 \%)$ siswa memiliki motivasi ekstrinsik kategori kurang, dan 1 orang (3.33\%) siswa memiliki motivasi ekstrinsik kategori kurang baik.

Berdasarkan hasil ‥-1: sis data diperoleh rata-rata motivasi 28 osik siswa dalam aktivitas pengemba iri bidang kepramukaan di Gugus depan SDN 22 Ulak Karang Utara Kota Padang yaitu 69.97. Hal ini menunjukkan bahwa motivasi ekstrinsik siswa dalam aktivitas pengembangan diri bidang kepramukaan di Gugus depan SDN 22 Ulak Karang Utara Kota Padang berada pada kategori "Sedang". Untuk lebih jelasnya dapat dilihat pada histogram 3 di bawah ini

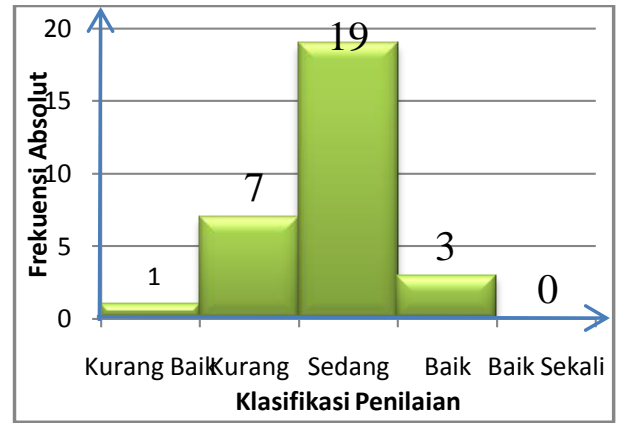

Motivasi Siswa Dalam Aktivitas Pengemangan ....6 Zarwan 


\section{Gambar 3. Histogram Motivasi Ekstrinsik}

\section{Pembahasan}

Motivasi adalah hal yang sangat penting dalam sebuah kegiatan, karena itu merupakan sebuah pendorong unuk berbuat. Hal ini sejalan dengan pendapat Pendapat.

Berdasarkan beberapa kutipan tentang pengertian motivasi, maka dapat ditarik suatu kesimpulan bahwa motivasi merupakan usaha yang didasari untuk menjaga tingkah laku menggerakan, dan mengarahkan seseorang agar ia terdorong untuk bertindak melakukan sesuatu dalam mencapai tujuan tertentu, misalnya seseorang yang memiliki motivasi dalam aktivitas pengembangan diri bidang kepramukaan.

Maka dia akan terdorong untuk bertindak dan melakukan kegiatan yang ada dalam aktivitas kepramukaan tersebut untuk mencapai hasil yang diinginkan. seperti motivasi instrinsik dan ekstrinsik.

Berdasarkan uraian tentang temuan motivasi intrinsik dan ektrinsik siswa dalam aktivitas pengembangan diri bidang kepramukaan di Gugus Depan SDN 22 Ulak Karang Utara Kota Padang, Maka dapat ditarik suatu kesimpulan bahwa motivasi siswa belum begitu baik. Atau motivasi siswa tersebut belum seperti yang diharapkan, tentu hal ini menjadi suatu pemikiran untuk menjadi solusi yang lain agar siswa memiliki motivasi yang tinggi terhadap kegiatan kepramukaan.

Kegiatan kepramukaan di sekolah dapat berjalan dengan baik, salah satu pendukungnya adalah motivasi siswa, baik motivasi intrinsik maupun motivasi ektrinsik.

Dengan demikian seorang individu dalam memperlihatkan tingkah lakunya tidak hanya dipengaruhi oleh faktor lingkungan. Tapi karena adanya energi yang berasal dari dalam diri individu itu sendiri. Kegiatankegiatan yang ditunjukkan oleh tingkah lakunya merupakan kehendaknya sendiri untuk mencapai tujuan yang diinginkan
Sedangkan timbulnya motivasi ekstrinsik tidak dilandasi oleh kondisi yang ada didalam diri siswa, melainkan keberadaannya akibat rangsangan dari faktor luar, sehingga tujuan yang hendak dicapai dari aktivitas tersebut berada diluar proses.

Berpedoman pada hasil analisis data dan uraian tentang motivasi siswa dalam aktivitas pengembangan diri bidang kepramukaan di Gugus Depan SDN 22 Ulak Karang Utara Kota Padang, perlu usaha dan upaya yang harus dilakukan agar siswa memiliki motivasi yang tinggi terhadap pelaksaan kegiatan kepramukaan ini.

Diantaranya adalah semua kegiatan dapat menyenangkan, menggembirakan, menarik bagi peserta didik dan dilaksanakan di alam terbuka. Kemudian peserta didik yang di ikut sertakan betul-betul di data yang punya bakat dan minat yang tinggi, pihak sekolah lebih memberi dukungan misalnya menambah sarana dan prasarana yang dibutuhkan dalam kegiatan kepramukaan tersebut begitu juga perlu bagi kakak pembina untuk mengetahui keadaan kesegaran jasmani peserta didik pada saat mengikuti kegiatan yang sifatnya dilaksanakan di alam terbuka dan sebagainya.

Selanjutnya bila diperhatikan dalam kegiatan kepramukaan di SD Negeri 22 Ulak Karang Utara Kota Padang, dapat berjalan dengan baik didukung oleh faktor lain sebagai faktor motivasi siswa.

Faktor tersebut adalah pendekatan guru sebagai pembina, bakat dan minat Peserta Didik terhadap kegiatan kepramukaan, sarana dan prasarana pendukung, dukungan kepala sekolah, dan perhatian orang tua.

Begitu juga dengan tingkat kesegaran jasmani peserta didik, kesegaran jasmani peserta didik perlu dan penting karena hal ini mempunyai pengaruh terhadap kesiapan peserta didik dalam mengikuti kegiatan kpramukaan yang berhubungan denagn aktivitas fisik.

Artinya peserta didik yang memiliki tingkat kesegaran jasmani yang rendah, 
mungkin terihat dari kemampuan fisiknya dalam mengikuti kegiatan, seperti kurang besemangat, sering cepat lelah, malas dan sering menguap adan wajahnya puca atau tidak segar.

Dengan keadaan siswa seperti ini akan dapat mempengaruhi kegiatan-kegiatan kepramukaan, terutama kegiatan yang dilakukan di alam terbuka yang banyak memrlukan kerja fisik.

\section{Kesimpulan}

Berdasarkan hasil penelitian tentang motivasi siswa dalam aktivitas pengembangan diri bidang kepramukaan di Gugus Depan SDN 22 Ulak Karang Utara Kota Padang. Maka peneliti memberikan saran saran yang membantu mengatasi masalah yang ditemui yang berkaitan dengan motivasi peserta didik terhadap kegiatan kepramukaan.

Adapun saran saran tersebut ditunjukan kepada:

1. Guru Penjasorkes ataupun kakak pembina kegiatan kepramukaan agar dapan meningkatkan motivasi siswa dalam kegiatan kepramukaan.

2. Kepala sekolah agar dapat menambahkan dan melengkapi sarana dan prasarana kapramukaan, kerena hal ini dapat meningkatkan motivasi siswa dalam mengikuti kepramukaan.

3. Siswa diharapkan agar meningkat motivasinya, karena kegiatan kepramukaan merupakan suatu kegiatan, menyenangkan, mengembirakan, mengasikkan, dan dapat membentuk budi pekerti dan watak serta akhlak yang baik.

4. Orang tua/wali murid agar lebih memberikan dukungan terhadap kegiatan yang dilaksanakan di sekoalh seperti kegiatan pramuka, karena semua kegiatan yang dilaksanakan disekoalh bermanfaat bagi anak.

\section{DAFTAR PUSTAKA}

Amti, Erman, dkk. (1992). i jan dan Konseling. Jakarta: Depdikbud.

Arikunto, Suharsimi. (1990). Manajemen Penelitian. Jakarta: Bumi Aksara.

Kwarnas. (2004). Anggaran Dasar Anggaran Rumah Tangga Kedudukan Hukum dan Lambangnya. Jakarta: Kwartir Nasional Gerakan Pramuka.

Undang-undang RI No 20.2003 tentang Sistem Pendidikan Nasional. Jakarta: Depdikbud.

Umar, Ali, (1990). Kurikulum dan Pengajaran. Padang: FPOK UNP Padang.

Yanis. M. (1989). Pelaksanaan Kurikulum di SMA Kodya Padang. Padang. Padang: Perpustakaan UNP. 
